\title{
Karakterisasi Pengaruh Temperatur Kalsinasi pada Intensitas Emisi Material Luminisensi ZnO:Zn
}

\author{
Diky Anggoro, ${ }^{*}$ Raidah Syarifah, Hasto Sunarno, Faridawati, dan Bachtera Indarto \\ Departemen Fisika-FIA, Institut Teknologi Sepuluh Nopember, Kampus ITS Sukolilo, Surabaya 60111
}

\begin{abstract}
Intisari
Karakterisasi pengaruh temperatur pada intensitas emisi material luminisensi $\mathrm{ZnO}: \mathrm{Zn}$ telah dilakukan. Penelitian ini dilakukan untuk mengetahui sifat optik dari ZnO:Zn sebagai material luminisensi dan akan dianalisis pengaruh temperatur terhadap intensitas emisi material luminisensi ZnO:Zn pada konsentrasi dopan 5\%. Sintesis $\mathrm{ZnO}$ dilakukan dengan metode solution phase dan dalam mendapatkan material luminisen $\mathrm{ZnO}$ :Zn digunakan metode milling. Spektrum absorbansi terbaik dihasilkan oleh $\mathrm{ZnO}: \mathrm{Zn}$ dengan temperatur tertinggi kalsinasi yaitu $400^{\circ} \mathrm{C}$. Berdasarkan dari karakterisasi spektrum photoluminniscence diketahui bahwa material luminisensi $\mathrm{ZnO}: \mathrm{Zn}$ dengan variasi temperatur mampu mengemisikan cahaya hijau dengan rentang panjang gelombang 523 $\mathrm{nm}$. Variasi temperatur yang diberikan akan berpengaruh pada tingginya intensitas emisi ZnO:Zn yang dihasilkan seiring meningkatnya temperatur yang diberikan.
\end{abstract}

\begin{abstract}
Characterization of the effect of temperature on emission intensity $\mathrm{ZnO}: \mathrm{Zn}$ luminance material has been carried out. This research was conducted to determine the optical properties of $\mathrm{ZnO}: \mathrm{Zn}$ as a luminous material and the effect of temperature on emission intensity of $\mathrm{ZnO}$ luminance material will be analyzed: $\mathrm{Zn}$ at $5 \%$ dopant concentration. $\mathrm{ZnO}$ synthesis was carried out using the solution phase method and in obtaining the $\mathrm{ZnO}: \mathrm{ZnO}$ :luminous material, the milling method was used. The best absorbance spectrum is produced by $\mathrm{ZnO}$ : $\mathrm{Zn}$ with the highest calcination temperature of $400^{\circ} \mathrm{C}$. Based on the photoluminniscence spectrum characterization it is known that $\mathrm{ZnO}: \mathrm{Zn}$ luminance material with temperature variations is capable of emitting green light with a wavelength range of $523 \mathrm{~nm}$. Temperature variation given will affect the high intensity of $\mathrm{ZnO}$ emission: $\mathrm{Zn}$ produced as the temperature increases.
\end{abstract}

KATA KUNCI: luminisensi, zinc oxide, emisi. http://dx.doi.org/10.12962/j24604682.v14i3.4165

\section{PENDAHULUAN}

Perkembangan teknologi tepat guna dalam mengurangi jumlah kebutuhan energi yang berlebihan telah banyak dijadikan sebagai topik dalam penelitian. Inovasi teknologi tepat guna ini harus yang mempunyai efisiensi yang tinggi, ramah terhadap lingkungan sekitar dan memiliki nilai jual yang ekonomis. Salah satunya dengan pembuatan lampu hemat energi seperti LED (Light Emitting Diodes) [1, 2]. LED telah banyak digunakan sebagai pengganti lampu pijar dikarenakan menggunakan daya yang lebih sedikit dan waktu pemakaian yang lebih lama [3]. Dalam pembuatan LED bahan semikonduktor memegang peranan yang sangat penting yaitu sifat luminisensinya sebagai penghasil cahaya, seperti pada bahan semikonduktor yang mulai digunakan sejak tahun 2010 yaitu $\mathrm{ZnO}[4,5]$. Ada beberapa karakteristik yang membedakan $\mathrm{ZnO}$ dengan material semikonduktor lain. $\mathrm{ZnO}$ memiliki nilai band gap $3,44 \mathrm{eV}$ pada temperatur rendah dan 3,37 eV pada temperatur kamar. Sebagai perbandingan, nilai band gap $\mathrm{GaN}$ 3,50 eV dan 3,44 eV pada temperatur rendah dan temperatur kamar [6], dimana GaN merupakan material

*E-MAIL: anggoro@physics.its.ac.id semikonduktor yang telah lebih dahulu digunakan. Sehingga material semikonduktor $\mathrm{ZnO}$ cocok digunakan sebagai bahan aplikasi fosfor dikarenakan sifatnya sebagai luminisensi kuat pada spektrum biru-hijau serta memiliki kelebihan yaitu keberadaannya yang melimpah di alam .

Material luminisensi merupakan material yang dapat mengkonversi berbagai macam energi menjadi radiasi elektromagnetik. Radiasi elektromagnetik yang diemisikan oleh fosfor biasanya dalam rentang cahaya tampak, namun terdapat juga di daerah spektrum ultraviolet atau infra merah. Ion fosfor dapat tereksitasi oleh banyak jenis energi [7], contohnya fotoluminisensi tereksitasi oleh foton, katodoluminisensi oleh elektron, elektroluminisensi oleh tegangan listrik, triboluminisensi oleh energi mekanik (contohnya penumbukan), $x$ ray luminisensi oleh sinar-x, kemoluminisensi oleh energi dari reaksi kimia dan sebagainya $[4,5]$. Material semikonduktor ditandai dengan adanya band gap, yaitu celah pita energi yang terletak diantara pita valensi yang berisi elektron penuh dengan pita konduksi yang kosong seperti terlihat pada Gambar 1. Celah pita energi ini berkaitan dengan sifat luminesen material: eksitasi tahap pertama pada semikonduktor adalah pada elektron di bawah pita konduksi dan hole pada pita valensi bagian atas.

Tren penelitian saat ini mengenai material luminisensi adalah mengurangi penggunaan doping bahan tanah jarang 


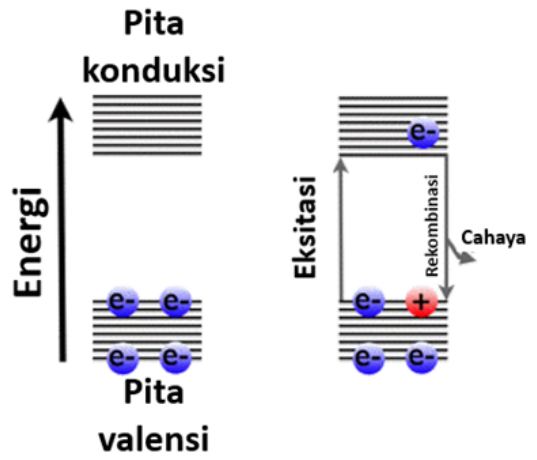

(a)

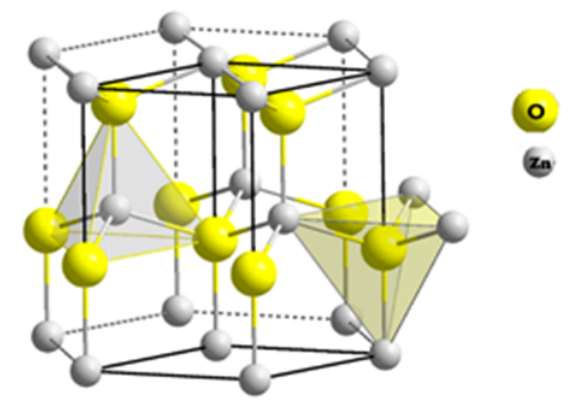

(b)

Gambar 1: Ilustrasi pita energi material semikonduktor dan struktur Wurtzite heksagonal $\mathrm{ZnO}$ [3].

[3], seperti namanya bahan doping berbasis tanah jarang selain langka keberadaanya harganya sangat mahal, sehingga pengembangan material luminisensi yang tidak berbasis doping tanah jarang sangat signifikan untuk dikembangkan dan di teliti lebih lanjut. $\mathrm{ZnO}$ merupakan salah satu persenyawaan dari logam $\mathrm{Zn}$ yang tergolong senyawa oksida. Secara umum, $\mathrm{ZnO}$ dapat dibuat dengan mereaksikan logam $\mathrm{Zn}$ dan oksigen pada temperatur rendah hingga temperatur tinggi, reaksi yang terjadi dapat dilihat pada Pers.(1):

$$
2 \mathrm{Zn}+\mathrm{O}_{2} \rightarrow 2 \mathrm{ZnO}
$$

Pada struktur kristal, $\mathrm{ZnO}$ mempunyai sifat piezoelectric dan thermionic serta memiliki kisi kristal dengan struktur wurtzit dan memiliki kisi terdiri dari $\mathrm{Zn}^{2+}$ dan $\mathrm{O}^{2-}$, setiap ion seng dikelilingi oleh ion $\mathrm{O}_{2}$ yang berbentuk tetrahedral $[8,9]$. Struktur sangat dipengaruhi oleh pita energi dan dinamika kisi. Besarnya band gap semikonduktor $\mathrm{ZnO}$ adalah 3,37 eV pada temperatur kamar dan besar eksitasi energi ikat $60 \mathrm{meV}$. Material $\mathrm{ZnO}$ memiliki band gap yang baik jika dibandingkan dengan material lainnya. $\mathrm{ZnO}$ sebagai material keramik semikonduktor merupakan bahan dengan konduktivitas yang berada diantara isolator dan konduktor [10, 11]. Material semikonduktor bersifat sebagai isolator pada temperatur yang sangat rendah dan bersifat sebagai konduktor pada temperatur ruangan. Semikonduktor sangat berguna karena sifat konduktifitasnya dapat dirubah dan dikontrol dengan memberi material lain atau menambahkan ketidakmurnian (doping).

\section{METODE PENELITIAN}

Langkah awal dalam penelitian ini yaitu menyiapkan bahan-bahan berupa serbuk $\mathrm{ZnO}$ (Zinc Oxide) yang berasal dari sintesis seng asetat dihidrat $\left(\mathrm{Zn}\left(\mathrm{CH}_{3} \mathrm{COO}\right)_{2} \cdot 2 \mathrm{H}_{2} \mathrm{O}\right.$ dengan menggunakan metode solution phase yang kemudian dikalsinasi pada temperatur tertentu sehingga didapatkan serbuk $\mathrm{ZnO}$. Proses sintesis seng oksida dengan metode solution phase menggunakan larutan yang dibuat dari prekursor 5 gram seng asetat dihidrat $\left(\mathrm{Zn}\left(\mathrm{CH}_{3} \mathrm{COO}\right)_{2} \cdot 2 \mathrm{H}_{2} \mathrm{O}\right.$ dilarutkan kedalam $100 \mathrm{ml}$ aquades dengan perlakuan pemanasan. Digunakan temperatur pemanasan $\pm 100^{\circ} \mathrm{C}$ selama 8 jam dan dilakukan di atas hot plate magnetic stirrer. Proses pemanasan larutan dimaksudkan agar aquades mencapai melting point dan untuk mempercepat pelarutan. Untuk mengikat $\mathrm{H}_{2} \mathrm{O}$ yang terdapat pada $\left(\mathrm{Zn}\left(\mathrm{CH}_{3} \mathrm{COO}\right)_{2} \cdot 2 \mathrm{H}_{2} \mathrm{O}\right.$, digunakan PEG (4000) sebanyak 11 gram. PEG dimasukkan pada larutan ketika aquades mencapai titik didih dalam kondisi pengadukan. $\mathrm{PEG}$ akan mengikat $\mathrm{H}_{2} \mathrm{O}$ tanpa melepas ikatan Zn dengan $\mathrm{CH}_{3} \mathrm{COO}$. Seng oksida yang larut memiliki butir yang sangat kecil sehingga larutan akan tampak bening. Selanjutnya sintesis material $\mathrm{ZnO}: \mathrm{Zn}$ dibuat dengan komponen utama yaitu $\mathrm{ZnO}$ yang telah berhasil dibuat sebelumnya dan seng asetat dihidrat $\left(\mathrm{Zn}\left(\mathrm{CH}_{3} \mathrm{COO}\right)_{2} .2 \mathrm{H}_{2} \mathrm{O}\right.$ sebagai prekursor dopan.

Dalam memperoleh material luminesensi $\mathrm{ZnO}: \mathrm{Zn}$, diberikan perlakuan milling selama 1 jam serta kalsinasi dengan temperatur tertentu. Untuk mendapatkan material luminesen $\mathrm{ZnO}: \mathrm{Zn}$ dalam bentuk serbuk, $\mathrm{ZnO}(0,4 \mathrm{~g})$ yang telah dihasilkan pada metode sebelumnya digerus dengan seng asetat dihidrat $\left(\mathrm{Zn}\left(\mathrm{CH}_{3} \mathrm{COO}\right)_{2} .2 \mathrm{H}_{2} \mathrm{O}(0,057 \mathrm{~g})\right.$ selama 1 jam. Digunakan konsentrasi dopan sebesar 5\%. Selanjutnya diberikan perlakuan kalsinasi dengan variasi temperatur 200, 300 , dan $400^{\circ} \mathrm{C}$ dengan holding time masing-masing 1 jam. Sampel hasil dari perlakuan kalsinasi kemudian digerus dengan tujuan untuk memperoleh serbuk $\mathrm{ZnO}: \mathrm{Zn}$ yang lebih homogen. Dalam mendapatkan informasi fasa, akan dikarakterisasi dengan menggunakan $X$-ray diffraction (XRD) dan untuk mengetahui sifat optik akan diuji dengan spektrometer Uv Vis serta dalam mengetahui emisi luminisensi akan diuji dengan PL Spektra.

\section{HASIL DAN DISKUSI}

\section{Analisis fasa $\mathrm{ZnO}$ dan $\mathrm{ZnO}: \mathrm{Zn}$}

Teknik preparasi material luminisensi ZnO melalui metode solution phase telah berhasil dilakukan pada penelitian ini. Serbuk $\mathrm{ZnO}$ berhasil diperoleh melalui proses kalsinasi dengan temperatur $800^{\circ} \mathrm{C}$. Untuk mengetahui fasa, struktur kristalit, dan ukuran kristal material luminesen $\mathrm{ZnO}$ tanpa dopan dilakukan pengujian XRD.

Setiap puncak yang muncul pada pola XRD mewakili satu bidang kristal. Puncak-puncak yang didapatkan dari data pengukuran akan disesuaikan dengan JCPDS atau standar difraksi sinar-X. Dengan menggunakan program Match! sebagai referensi database kisi Kristal berbagai senyawa, maka diper- 


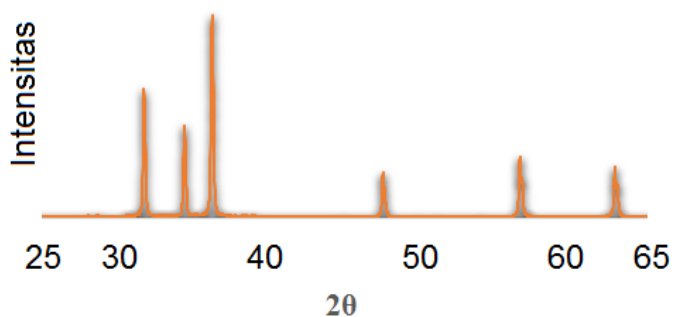

Gambar 2: Pola XRD ZnO pada temperatur $800^{\circ} \mathrm{C}$.

oleh nilai $2 \theta$ yang bersesuaian untuk masing-masing Kristal. Uji XRD dilakukan dengan jangkauan sudut $2 \theta$ dari sudut $25^{\circ}$ sampai dengan $65^{\circ}$. Pola XRD $\mathrm{ZnO}$ pada temperatur $800^{\circ} \mathrm{C}$ dapat dilihat pada Gambar 2.

Pola XRD pada Gambar 2 menunjukkan bahwa puncakpuncak difraksi $\mathrm{ZnO}$ pada temperatur $800^{\circ} \mathrm{C}$ terdapat pada $2 \theta: 31,75 ; 34,41 ; 36,23 ; 47,53 ; 56,57$; 62,84 [PDF 96900-4180]. Pada pola difraksi $\mathrm{ZnO}$ yang telah diuji tidak ditemukan fase lain. Hasil ini sesuai dengan pola difraksi $\mathrm{ZnO}$ struktur heksagonal dengan space group $\mathrm{P} 63 \mathrm{mc}$ dan parameter unit cell $\mathrm{a}=3,253 \AA$, dan $\mathrm{c}=5,2 \AA$,. Dalam memperoleh ukuran kristal dapat dihitung dengan menggunakan persamaan Scherrer [3, 12]. Dari perhitungan yang telah dilakukan diperoleh hasil rata-rata ukuran kristal $\mathrm{ZnO}$ pada temperatur $800^{\circ} \mathrm{C}$ yaitu sebesar $180,77 \mathrm{~nm}$.

Setelah memperoleh informasi fasa yang terbentuk pada $\mathrm{ZnO}$, maka dibuat material luminisensi $\mathrm{ZnO}: \mathrm{Zn}$ dengan variasi temperatur kalsinasi. ZnO dengan dopan $\mathrm{Zn}$ sebagai material luminesensi telah berhasil didapatkan melalui teknik milling (penggerusan). Setelah melalui proses milling, sampel diberi perlakuan kalsinasi pada variasi temperatur 200, 300 dan $400^{\circ} \mathrm{C}$. Dilakukan pengujian XRD untuk mengetahui fasa yang terbentuk. Berdasarkan dari hasil uji yang telah dilakukan didapatkan fasa tunggal yang terbentuk yaitu $\mathrm{ZnO}$ dengan struktur wurtzit tanpa adanya fasa lain. Hal ini dibuktikan dengan pola XRD yang terbentuk pada Gambar 3 yang menunjukkan bahwa puncak-puncak difraksi $\mathrm{ZnO}: \mathrm{Zn}$ terdapat pada $2 \theta: 31,75 ; 34,41 ; 36,25 ; 47,53 ; 56,50 ; 62,86$ untuk temperatur $200^{\circ} \mathrm{C}, 31,68 ; 34,50 ; 36,34 ; 47,64 ; 56,75$ ; 62,93 untuk temperatur $300^{\circ} \mathrm{C}$, dan 31,$76 ; 34,42$; 36,24 ; 47,$54 ; 56,58 ; 62,86[96-230-0113]$ untuk temperatur $400^{\circ} \mathrm{C}$ yang dapat dilihat pada Gambar 3.

Pada pola difraksi material luminisensi $\mathrm{ZnO}: \mathrm{Zn}$ yang telah diuji tidak ditemukan puncak baru atau dengan kata lain fasa yang terbentuk merupakan fasa tunggal. Hal ini membuktikan bahwa doping $\mathrm{Zn}$ tidak mempengaruhi fasa $\mathrm{ZnO}$ yang terbentuk. Hasil ini sesuai dengan pola difraksi $\mathrm{ZnO}$ struktur heksagonal dengan space group $\mathrm{P} 63 \mathrm{mc}$ dan parameter unit cell $\mathrm{a}=3,2494 \AA$, dan $\mathrm{c}=5,2054 \AA$.

\section{Analisis Sifat Optik Absorbansi dan Transmitansi ZnO dan ZnO:Zn}

Spektrofotometer UV-Vis merupakan suatu gambaran yang menyatakan hubungan antara panjang gelombang atau frekuensi serapan terhadap intensitas serapan. Pengujian

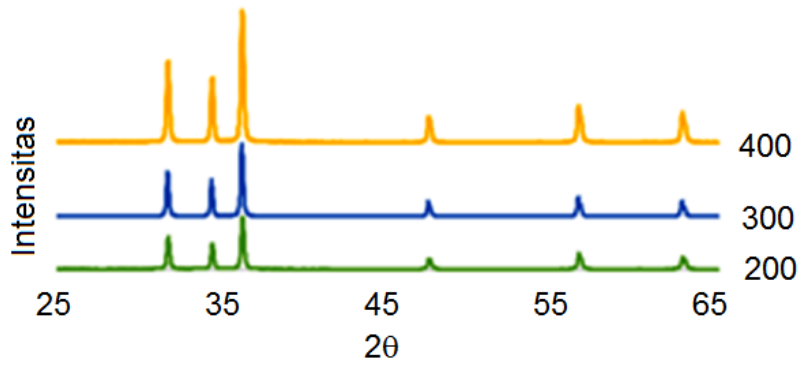

Gambar 3: Pola XRD ZnO:Zn dengan variasi temperatur 200, 300, dan $400^{\circ} \mathrm{C}$.

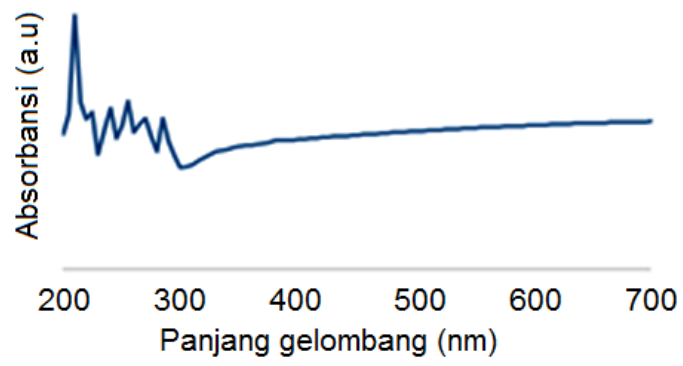

(a)

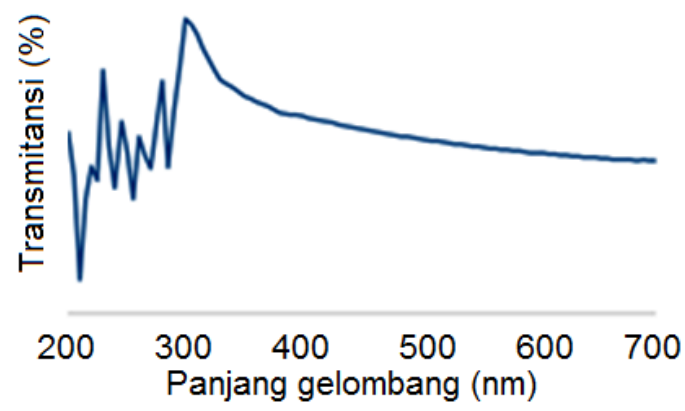

(b)

Gambar 4: Spektrum absorbansi dan transmitansi $\mathrm{ZnO}$ pada temperatur kalsinasi $800^{\circ} \mathrm{C}$.

spektrofotometer UV-Vis-NIR dilakukan pada $\mathrm{ZnO}$ dengan temperatur kalsinasi $800^{\circ} \mathrm{C}$ untuk mengetahui absorbansi dan transmitansi dari $\mathrm{ZnO}$ pada rentang panjang gelombang 200 hingga $700 \mathrm{~nm}$.

Pada Gambar 4 menunjukkan kemampuan absorbansi $\mathrm{ZnO}$ pada rentang sinar ultraviolet yaitu panjang gelombang 200 $\mathrm{nm}$ sampai 300nm dengan absorbansi maksimum pada panjang gelombang $210 \mathrm{~nm}$. Absorbansi merupakan kemampuan suatu material dalam menyerap suatu cahaya atau energi. Absorbansi pada suatu material luminisen sangat berpengaruh terhadap intensitas emisi pada material $\mathrm{ZnO}$, sedangkan terlihat pada Gambar 4 yang menunjukkan transmitansi dari $\mathrm{ZnO}$ dengan rentang panjang gelombang maksimum 300 $\mathrm{nm}$. Apabila suatu molekul menyerap radiasi ultraviolet, di dalam molekul tersebut terjadi perpindahan tingkat energi elektron-elektron ikatan pada orbital molekular paling luar 


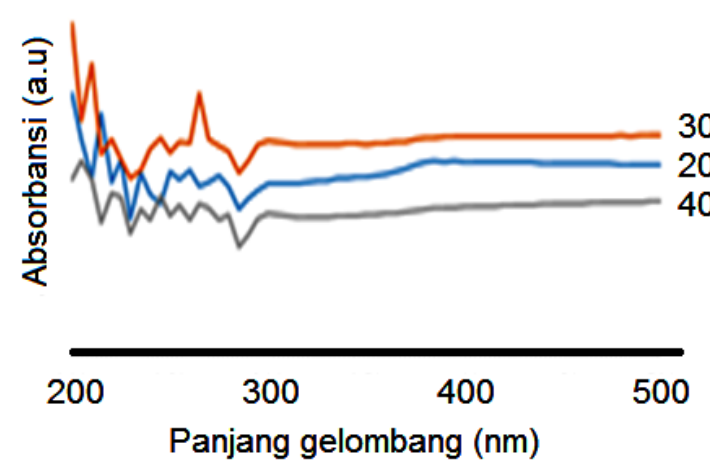

(a)

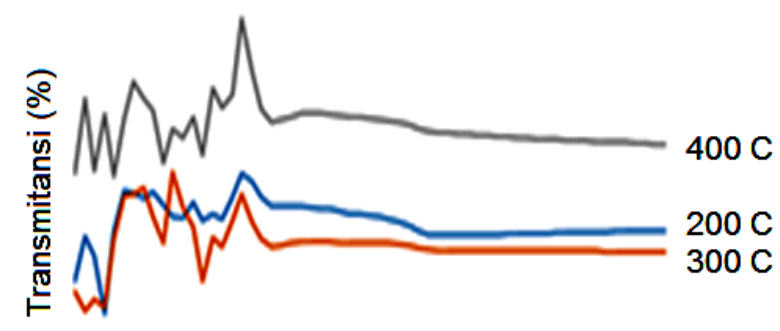

200 300 400 500 Panjang gelombang (nm)

(b)

Gambar 5: Spektrum absorbansi dan transmitansi $\mathrm{ZnO} \mathrm{Zn}$ dengan variasi temperatur kalsinasi 200,300 , dan $400^{\circ} \mathrm{C}$.

dari tingkat energi yang lebih rendah ke tingkat energi yang lebih tinggi. Transmitansi merupakan bagian cahaya yang diteruskan melalui larutan.

Proses pengujian sifat optik $\mathrm{ZnO}: \mathrm{Zn}$ dilakukan dengan mengunakan alat UV-Vis untuk memperoleh nilai absorbansi dan transmitansi pada rentang panjang gelombang sinar ultraviolet sampai cahaya tampak. Pada proses spektroskopi UV-Vis digunakan spectrometer UV-Vis dengan sampel larutan koloid $\mathrm{ZnO}: \mathrm{Zn}$ dengan aquades sebagai pelarut yang telah melalui proses kalsinasi dengan variasi temperatur. Hasil pengujian sifat optik $\mathrm{ZnO}: \mathrm{Zn}$ dengan menggunakan spektroskopi UV-Vis menghasilkan spektra absorbansi $\mathrm{ZnO}: \mathrm{Zn}$ pada rentang panjang gelombang antara 200 sampai $500 \mathrm{~nm}$.

Gambar 5 menunjukkan absorbansi dan transmitansi maksimum $\mathrm{ZnO}: \mathrm{Zn}$ berada pada temperatur $400^{\circ} \mathrm{C}$ dibandingkan dengan $\mathrm{ZnO}: \mathrm{Zn}$ pada temperatur 200 dan $300^{\circ} \mathrm{C}$. Hal ini ditunjukkan dari terbentuknya puncak spektrum maksimum berada pada rentang panjang gelombang $290 \mathrm{~nm}$. Absorbansi cahaya pada suatu material merupakan bentuk interaksi gelombang cahaya dan atom molekulnya. Energi cahaya diserap oleh atom untuk bertransisi ke tingkat energi yang lebih tinggi. Pada material luminisensi $\mathrm{ZnO}: \mathrm{Zn}$ untuk temperatur kalsinasi $400^{\circ} \mathrm{C}$ memiliki kemampuan absorbansi lebih baik dibandingkan dengan pada temperatur $200^{\circ} \mathrm{C}$ dan $300^{\circ} \mathrm{C}$ yang berkebalikan dengan kemampuan transmitansinya. Hal ini disebabkan tingginya absorbansi berpen-

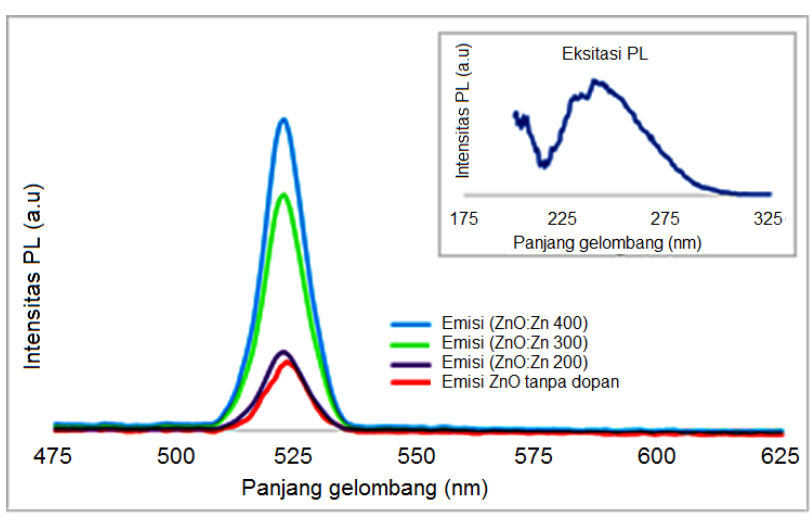

Gambar 6: Spektrum PL ZnO:Zn dengan variasi temperatur 200, 300 , dan $400^{\circ} \mathrm{C}$.

garuh pada banyaknya cahaya yang akan diserap sedangkan cahaya yang akan dilewatkan sedikit.

\section{Analisis emisi material luminisensi ZnO:Zn}

Intensitas emisi yang dipancarkan pada masing-masing $\mathrm{ZnO}: \mathrm{Zn}$ dengan variasi temperatur 200,300 dan $400^{\circ} \mathrm{C}$ meningkat seiring dengan meningkatnya temperatur pada rentang panjang gelombang 500-530 nm. Dengan demikian warna pada cahaya tampak yang dihasilkan akan semakin kuat atau terang. Puncak intensitas emisi pada $\mathrm{ZnO}$ tanpa dopan dan dengan dopan $\mathrm{Zn}$ terletak pada $532 \mathrm{~nm}$ yang merupakan rentang panjang gelombang warna hijau sesuai dengan Gambar 6 .

Pada Gambar 6 emisi yang tertinggi dipancarkan oleh $\mathrm{ZnO}: \mathrm{Zn}$ pada temperatur $400^{\circ} \mathrm{C}$ dengan panjang gelombang maksimum 525,5 nm. Sebaliknya pada panjang gelombang yang sama, emisi justru tampak menurun yaitu pada temperatur $200^{\circ} \mathrm{C}$. Semakin tinggi temperatur kalsinasi semakin banyak atom yang dapat meninggalkan posisi kesetimbangannya dan semakin banyak kekosongan yang dapat dijumpai pada kristal. Akibat dari banyaknya kekosongan yang terjadi maka dopan akan masuk menggantikan kekosongan pada kristal. Apabila banyak energi foton yang terserap maka akan semakin banyak elektron yang tereksitasi hal ini menyebabkan intensitas emisi yang akan dipancarkan turut membesar. Hal ini menunjukkan bahwa temperatur temperatur akan berpengaruh terhadap emisi yang dipancarkan. Temperatur kalsinasi yang dilakukan belum mencapai titik quenching, sehingga bila diberikan variasi temperatur kalsinasi yang lebih tinggi besar kemungkinan intensitas dari kurva PL semakin tinggi dan menghasilkan emisi cahaya hijau yang lebih baik.

\section{SIMPULAN}

Material luminisensi $\mathrm{ZnO}: \mathrm{Zn}$ untuk temperatur kalsinasi $400^{\circ} \mathrm{C}$ memiliki kemampuan absorbansi yang baik yaitu pada rentang panjang gelombang sinar ultraviolet 290 $\mathrm{nm}$ dan berkebalikan dengan kemampuan transmitansinya. Hal ini disebabkan tingginya absorbansi berpengaruh pada 
banyaknya cahaya yang akan diserap sedangkan cahaya yang akan dilewatkan sedikit. Pengaruh temperatur terhadap intensitas emisi material luminisen $\mathrm{ZnO}: \mathrm{Zn}$ pada konsentrasi dopan $5 \%$ yaitu semakin tinggi temperatur pada 200,300 , dan $400^{\circ} \mathrm{C}$ dihasilkan intensitas emisi yang semakin tinggi. Emisi yang tertinggi dipancarkan oleh $\mathrm{ZnO}: \mathrm{Zn}$ pada temperatur $400^{\circ} \mathrm{C}$ dengan panjang gelombang maksimum 525,5nm.
[1] C. Panatarani, D. Anggoro, and F. Faizal, "Solution Phase Synthesis and Photoluminescent Properties of Nanocrystal $\mathrm{LaPO}_{4}$ : $\mathrm{Eu}^{3+}$,, AIP Conf. Proc., vol. 1284, pp. 77-80, 2010.

[2] D. Anggoro and T. Winata, "Penumbuhan Silikon Nanowire dengan Nanokatalis Perak menggunakan Metode HWC-In PlasmaVHF-PECVD melalui Optimasi Tekanan”, J. Fis. dan Apl., vol. 10, pp. 84-89, 2014.

[3] D. Anggoro, R. Yuniasari, and H. Sunarno, "Pengaruh Konsentrasi Doping terhadap Intensitas Emisi Material Luminisensi ZnO:Zn", J. Fis. dan Apl., vol. 14, pp. 1-4, 2018.

[4] B.G.G. Blasse, "Luminescent Materialse", Springer Netherlands, 1994.

[5] S. Nakamura, "The Blue Laser Diode:GaN Based Light Emitter and Lasers", Springer, Berlin, 1997.

[6] S. Chakraborty and P. Kumbhakar, "Effect of polyethylene glycol on the particle size and photoluminescence emissions characteristics of chemically synthesized $\mathrm{ZnO}$ nanoparticles", Opt. Commun., vol. 318, pp. 61-66, 2014.

[7] D. Anggoro and Endarko, "Evaluating Capacitive Deionization for Measurements of the Salt-Removal of $\mathrm{NaCl}, \mathrm{KCl}$ and $\mathrm{MgCl}$ at Various Cell Voltages", Adv. Mater. Res., vol. 1112, pp. 271274, 2015.

[8] R. Bhaskar, A. R. Lakshmanan, M. Sundarrajan, T. Ravishankar, M. T. Jose, and N. Lakshminarayan, "Mechanism of green luminescence in ZnO", Indian J. Pure Appl. Phys., vol. 47, no. 11, pp. 772-774, 2009.

[9] M. A. Tshabalala, B. F. Dejene, and H. C. Swart, "Synthesis and characterization of $\mathrm{ZnO}$ nanoparticles using polyethylene glycol (PEG)", Phys. B Phys. Condens. Matter, vol. 407, no. 10, pp. 1668-1671, 2012.

[10] J. Xu, "Luminescence in ZnO", Mater. luminiscence, vol. 78, December, pp. 41-47, 2004.

[11] N. Shakti, "Structural and Optical Properties of Sol-gel Prepared ZnO Thin Film", Appl. Phys. Res., vol. 2, no. 1, pp. 19-28, 2010.

[12] D. Anggoro, M.S. Muntini, I. Fatimah, Sudarsono, "Modelling Dynamics of ZnO Particles in The Spray Pyrolisis Reactor Tube", UNEJ e-Proceeding, vol. 1, pp. 177-180, 2017. 